
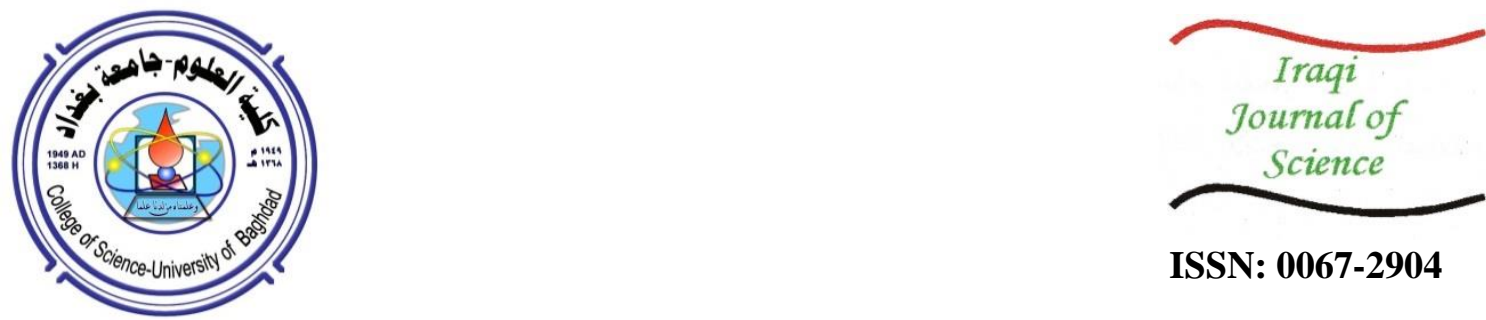

ISSN: 0067-2904

\title{
Evaluation of the Performance of Silicon Solar Cell with Fresnel Lens as Photovoltaic Solar Concentrator
}

\author{
Ali Hussien Obaid, Emad Jaleel Mahdi, Assma Hassan Muslem, Ammar Noori Jafer, \\ Salah Subhi Abed, Tariq Yasseen Khuder \\ Ministry of Sciences and Technology
}

Received: $17 / 9 / 2020$

Accepted: 29/3/2021

\begin{abstract}
In this paper, the performance of a silicon cell with a Fresnel lens (FL) for building a solar photovoltaic concentrator system was evaluated; the solar concentrator is a Fresnel lens, which is a point concentrator made of polymethylmethacrylate (PMMA) as a thin lens for the optics system.

As the radiation from the sun on the solar cell is concentrated to the levels of solar radiation of $750,1300,1930,2600,4250,7250$, and 10500) $\mathrm{W} / \mathrm{m}^{2}$, the work was conducted at the midday in summer weather conditions, with ambient temperatures ranging $40-45{ }^{\circ} \mathrm{C}$. The evaluation was performed in three cases; each case was conducted in succession. The performance of the cell was evaluated first without a cooling system, and then it was evaluated using the heat-sink (phenolic $(\mathrm{pcb})$ printed circuit boards type). Finally, the fan with the heat-sink was used as a cooling system, which was more effective in dissipating the heat generated in the solar cell. The evaluation, based on the current and voltage (I-V) results with cell temperature, showed the following efficiency values for the abovementioned three cases, respectively:(6.91, 7.76,6.65, 7.77,6.27, 4.74,3.37 ) \%, (7.41, 9.21, $7.5,8.31$, $9.71,7.53,4.72) \%$, and $(7.63,9.34,7.57,8.37,10.2,7.75,4.7) \%$.
\end{abstract}

Keywords: - Si solar cell , Concentrating Photovoltaic (CPV) system, Fresnel Lens Concentrator, Solar Concentrator System, Concentration Ratio.
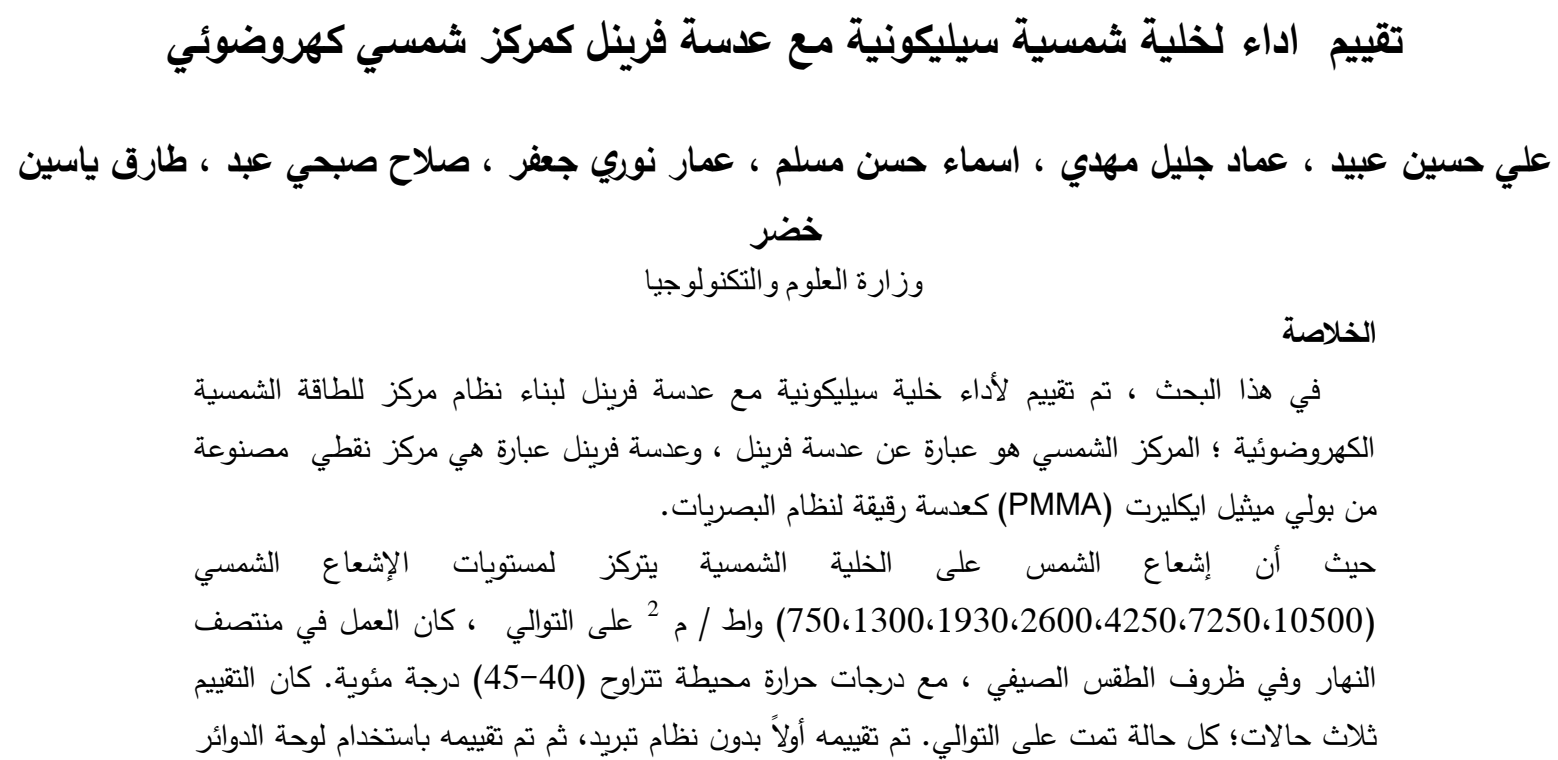

*Emad.jaleel@yahoo.com 


$$
\begin{aligned}
& \text { المطبوعة ذات المشتت الحراري (phenolic (pcb). أخيرًا، تم استخدام المروحة ذات المشتت الحراري كنظام }
\end{aligned}
$$

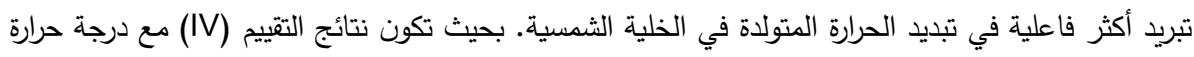

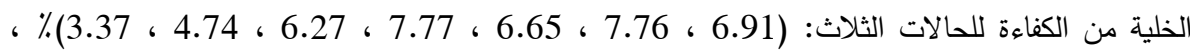

$$
\begin{aligned}
& \text { (7.41) }
\end{aligned}
$$

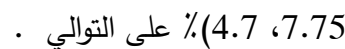

\section{Introduction}

The first concentrating photovoltaic (CPV) systems were proposed by Sandia National Labs in the late 1980s [1]. The solar CPV cell is a PV solar energy system that is used to convert energy from solar energy into electrical energy. This conversion is achieved by using solar cells made of semiconducting materials at highly concentrated solar radiation levels through special optical lenses [2].

The solar CPV system uses solar concentrators as the optical lenses. Due to the integration of lenses as a solar concentrator system, these systems depend on their operation on direct solar radiation and the percentage of the sun that reaches them. Thus, a two-axis solar tracking system is needed to track the position of the sun from sunrise to sunset [3]. At high levels of solar radiation, the efficiency of such photovoltaic systems may decrease due to the limitations of optical systems of around $28-40 \%$ [4].

There are various concepts for the photovoltaic systems, depending on the optical system used and the number of lenses [5]. The more efficient these systems, the more expensive they will be. Depending on the materials and technology used, the best of these systems is the one that combines high efficiency and low cost [6].

These types of solar concentrators are defined according to their concentration ratio; the common definition is the ratio between the area of the optical system (lens or mirror) and the effective area of the solar cell. The active area of the solar cell is designed to be completely covered by the focused radiation [7].

These different systems can be classified according to the concentration ratio. The concentration ratio that can be achieved by these optical elements range from 500 to up to 1000 or even $2000 \mathrm{~W} / \mathrm{m}^{2}$ [8].

As a result, there must be an optimal concentration which can decide the optimal cost of the FL concentrating the optics-based photovoltaic solar system. The optimal concentration is calculated as follows [9]:

$$
\text { Conc. }=1+2 \sum_{i=1}^{N} \cos (\theta(i))
$$

where conc. is the concentration of the FL concentrator based on the refraction angles $(i)$ of FL facets, $N$ is half the number of facets, and the value of 1 in this expression represents the concentration of the central facet where the refraction angle $\theta$ is zero.

Ideally, the efficiency of the solar cells should be increased with the concentration ratio of solar radiation [10]. However, the performance of standard silicon solar cells illuminated by the high level of sunlight decreases due to series resistance losses (Shunt Resistance) in addition to the rise in the cell temperature. Solar cells are manufactured to work with the highest rate of solar radiation of 1000 $\mathrm{W} / \mathrm{m}^{2}[11]$.

The CPV aims to reduce the price of conventional photovoltaic electricity by using less amount of solar cell material, in addition to reducing the total collection area of the system with more power is installed at the same time [12].

The CPV technology requires a climate with high direct solar radiation and clear sky. In geographic areas with annual radiation rates below $1500 \mathrm{kWh} / \mathrm{m}^{2} /$ year, the use of conventional solar photovoltaic is more favorable [13].

The accurate prediction of photovoltaic system performance under realistic conditions is a key issue that has important ramifications for the cost of electricity. Assuming that only radioactive recombination takes place in p-n junction, single-junction solar cells may be represented by the equivalent circuit. The current (I) collected at the output of the cell depends on the generated current $\left(\mathrm{I}_{\mathrm{L}}\right)$, the current diverted to the diode $\mathrm{I}_{\mathrm{D}}$, and the shunt current $\left(\mathrm{I}_{\mathrm{Sh}}\right)$, as follows:[14].

$$
\mathrm{I}=\mathrm{I}_{\mathrm{L}}-\mathrm{I}_{\mathrm{D}}-\mathrm{I}_{\mathrm{sh}}
$$


$\left(I_{D}=I_{0}\left[\exp \left(\frac{q\left(V+I R_{S}\right)}{k_{B} T}\right)-1\right]\right)$ and $\left(I_{S H}=\frac{V+I R_{S}}{R_{S h}}\right)$ depend on the output tension $(V)$ and the parallel resistance $\left(\mathrm{R}_{\mathrm{sh}}\right)$. The current voltage equation takes the form:

$$
I=I_{L}-I_{0}\left[\exp \left(\frac{q\left(V+I R_{S}\right)}{k_{B} T}\right)-1\right]-\frac{V+I R_{S}}{R_{S h}}
$$

where $I_{0}$ is the reverse saturation current of the diode. The series resistance $\left(R_{S}\right)$ represents the bulk resistance (due to the fact that solar cell materials are not perfect conductors), and the parallel resistance $\mathrm{R}_{\mathrm{P}}$ is caused by leakage of current from one terminal to the other due to poor insulation. So, the ideal solar cell would have $\mathrm{R}_{\mathrm{S}}=0$ and $\mathrm{R}_{\mathrm{sh}}=\infty$ : [15]

$$
\mathrm{I}=\mathrm{I}_{\mathrm{L}}+\mathrm{I}_{0}\left[\exp \left(\frac{\mathrm{qV}}{\mathrm{k}_{\mathrm{B}} \mathrm{T}}\right)-1\right]
$$

Solar concentrators use only direct solar radiation and do not use diffuse radiation from clouds and various atmosphere components. This means that this type of system is effective when the ratio of direct solar radiation is higher. Solar concentrators are often toward the position of the sun. Thus, the type of solar tracking system used in such techniques is determined. The tracking system may have two axes in the case of the point focus and the tracking system may be one axis in the case of the longitudinal focus. The behavior of the solar cell under concentrated solar radiation is that it will double the value of the current generated; the short circuit current $\mathrm{I}_{\mathrm{sc}}$ is relative to solar radiation:[16]

$$
\mathrm{I}_{\mathrm{sc}}(\mathrm{X})=\mathrm{XI}_{\mathrm{sc}}(1)
$$

$\mathrm{X}=$ concentration ratio

On the other hand, the open circuit voltage is calculated as follows:

$$
V_{o c}(X)=\left(\frac{K T}{q}\right) \ln \left(\frac{I_{s c}(X)}{I_{0}}+1\right) \approx\left(\frac{K T}{q}\right) \ln \left(X \frac{I_{s c}}{I_{0}}\right)=V_{o c}(1)+\left(\frac{K T}{q}\right) \ln X \ldots
$$

where $\mathrm{I}_{0}=$ the diode dark saturation current, $\mathrm{q}=$ the electron charge, $\mathrm{T}=$ the temperature, $\mathrm{K}=$ the Boltzmann constant.

Therefore if $G(X)$ is the irradiance increases to $X$, so the efficiency as a function to $X$ is:

$$
\eta(X)=\frac{V_{o c}(X) I_{S C}(X) F F}{G(X)}=\eta(1)\left(1+\frac{\left(\frac{K T}{q}\right) \ln X}{V_{o c}(1)}\right)
$$

The rate of increase in efficiency in the ideal solar cell is a logarithmic ratio of the concentration of radiation.

The open circuit voltage of a silicon cell is about $0.6 \mathrm{~V}$ without concentration .This value can increase to about $10 \%$. The heat dispersed power across the solar cell's finite series resistance $R_{S}$ is:[17]

$$
\mathrm{P}_{\text {loss }}=I^{2} R_{S}
$$

The I current passing through the solar cell is relative to the concentrated solar radiation $X$. The power losses are:

$$
\mathrm{P}_{\mathrm{loss}} \cong X^{2} I_{s c}(1)^{2} R_{S}
$$

This power grows rapidly depending on the increase in $\mathrm{X}$.

Thus, the optimum concentration is about:

$$
\mathrm{X} \cong \frac{\left(\frac{k T}{q}\right)}{I_{S c}(1) R_{S}}
$$

The maximum concentration ratio that can be obtained can be affected by several factors, including the amount of parallel radiation reaching the Earth, and the nature of the solar cell material that increases the concentration of focused radiation, and the reduction in the error rate in the solar tracking system. These factors limit the concentration ratio of solar radiation:[18].

$$
X_{\text {max }}=\frac{n^{2}}{\sin ^{2} \theta_{c}}
$$

where: $\theta_{c}=\theta_{\text {sun }}+\theta_{e} \quad \theta_{\text {sun }}$ : is the half angle subtended by the suns ray , $\theta_{\mathrm{e}}$ : is the tracking error $\left(0.1^{\circ}-3^{\circ}\right)$, and $\mathrm{n}$ is the refractive index of adjoining medium, $\mathrm{n}>1.6$. The aim of this work is to study the photovoltaic solar concentrators system using a silicon cell with a Fresnel lens.

\section{Experimental Apparatus and Procedures}

For system's description, the system shown in Figure-1 is modular in structure with each solar cell capable to generate electricity. The solar cell is the main component, acting as a better absorber of photon energy from a wider spectral range of sunlight, were the peak response is in the near-infrared region. The monocrystalline solar cells were purchased from Al-Zawraa Company, Al- Mansour 
Branch, Baghdad, Iraq. The solar cell has dimensions of $2 \times 2.5 \mathrm{~cm}$, and it was tested in standard conditions ( solar radiation $=1000 \mathrm{~W} / \mathrm{m}^{2}, A M=1.5$, solar cell temperature $=25^{\circ}$ ), by using the solar simulator for I-V characteristics, as shown in Table-1.

Table 1- Current and voltage (I-V) characteristics of the monocrystalline solar cell

\begin{tabular}{|c|c|c|c|c|c|c|c|c|c|}
\hline $\begin{array}{c}\text { No. } \\
\text { Cell }\end{array}$ & $\begin{array}{c}\text { Cell } \\
\text { type }\end{array}$ & $\begin{array}{c}\text { Irradiance } \\
\left(\mathbf{W} / \mathbf{m}^{\wedge} \mathbf{2}\right)\end{array}$ & $\begin{array}{c}\mathbf{I}_{\mathbf{s c}} \\
(\mathbf{m A})\end{array}$ & $\begin{array}{c}\mathbf{V}_{\mathbf{o c}} \\
(\mathbf{V})\end{array}$ & $\begin{array}{c}\mathbf{P}_{\mathbf{m p}} \\
(\mathbf{W})\end{array}$ & $\begin{array}{c}\text { Cell eff. } \\
\eta(\boldsymbol{\%})\end{array}$ & $\begin{array}{c}\mathbf{I}_{\mathbf{m p}} \\
(\mathbf{m A})\end{array}$ & $\begin{array}{c}\mathbf{V}_{\mathbf{m p}} \\
(\mathbf{V})\end{array}$ & $\mathbf{F . F}$ \\
\hline 1 & mono & 1000 & 84.6 & 0.58 & $\begin{array}{c}0.035 \\
8\end{array}$ & 7.2 & 77.9 & 0.46 & 0.73 \\
\hline
\end{tabular}

The type of Fresnel lens used is a point focus made from PMMA as an optics system with thin lens, as shown in Table-2.

Table 2- The specifications of the pointer Fresnel lens used in the current study for.....

\begin{tabular}{|c|c|}
\hline Specifications & Pointer Fresnel lens \\
\hline focus & point \\
\hline dimension & $163 \times 107(\mathrm{~mm})$ \\
\hline Focal Length $(\mathrm{mm})$ & $120(\mathrm{~mm})$ \\
\hline Thick & $2(\mathrm{~mm})$ \\
\hline
\end{tabular}

As the optical system, a Fresnel lens was used to focus solar radiation on the solar cell. For cooling the solar cell, a heat-sink (CPU Deep cooler) with a fan of $2.4 \mathrm{~W}$ operation in $12 \mathrm{~V}$ was used as a cooling system. Thermal paste was applied as a thin layer on the surface between the heat-sink and the cell. It helps increase the heat conductivity from the solar cell to the heat-sink.

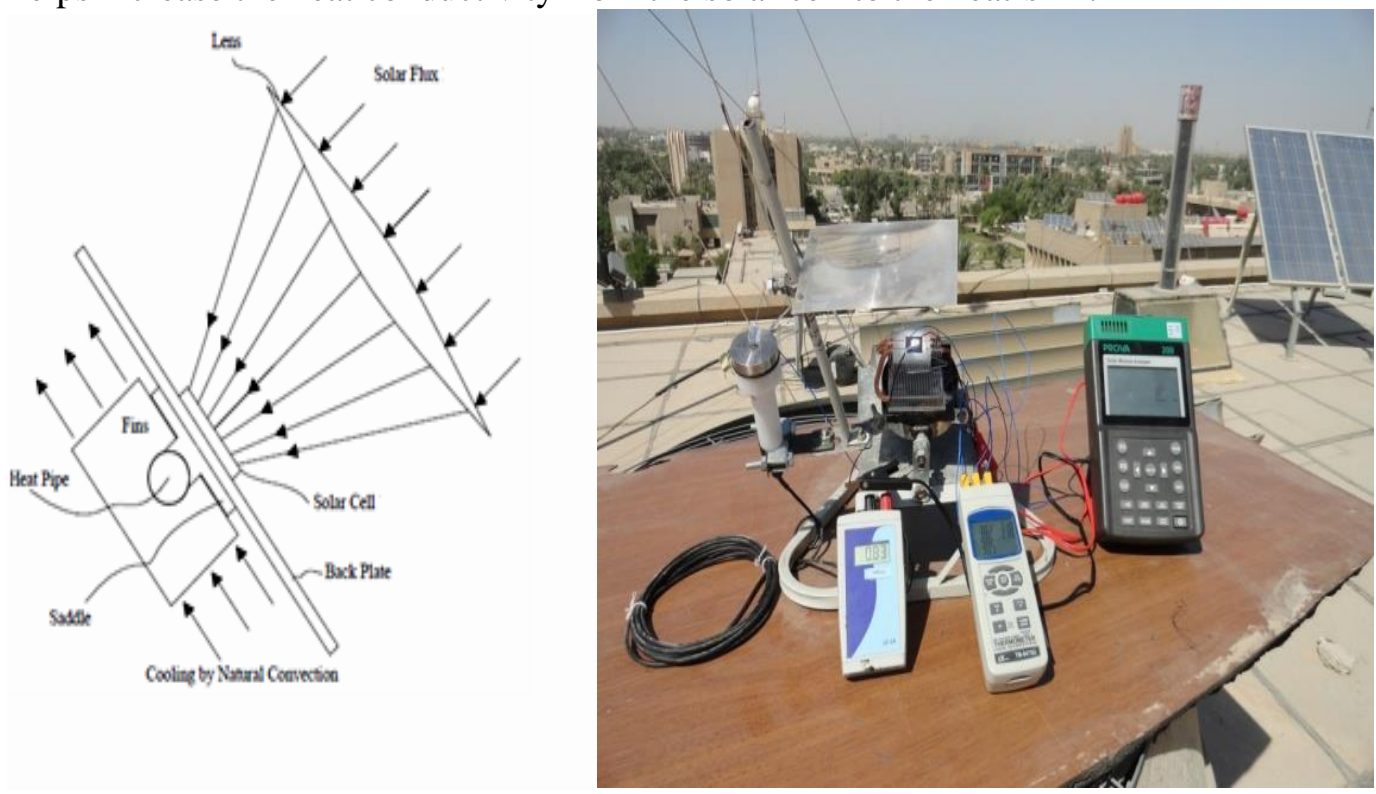

Figure 1- the setup of the experimental parts

This prototype was designed for a dual-axis tracker, which was available for testing and, hence, we used it for this testing.

The effect of different solar radiation rates on solar cell performance and power generation value was evaluated. By changing the focal length of the Fresnel lens, different solar radiation rates were obtained, covering the effective area of the solar cell. After that, different values of the electrical properties of the silicon solar cell were obtained. The results of the solar cell electrical properties curves, current, voltage, power and efficiency values were obtained.

Solar power-meter, manufactured by Hukseflux thermal sensors, Netherlands, with measuring range from 0 to $10,999 \mathrm{~W} / \mathrm{m}^{2}$ and resolution of $1 \mathrm{~W} / \mathrm{m}^{2}$, was used to measure the solar radiation intensity with and without using the concentrator. Its probe was located close to the tested solar cell against the Fresnel lens. 
The thermometer used to measure PV cell's surface temperature and ambient temperature was the Contact thermometer, 4-channel PCE-T390 of K-Type sensors TF-500.

A PV analyzer (Prova) was connected directly to the solar cells to determine current-voltage and power-voltage characteristics of solar cell.

\section{Results and Discussion}

The performance of the solar cell system was evaluated for the tested three cases; without (heat - sink), with (heat - sink), and with (heat - sink + fan).

The following curves illustrate the effects of solar radiation rates on changing the solar cell temperature. Figure- 2 shows the difference between the behaviors of the abovementioned three cases of the system.

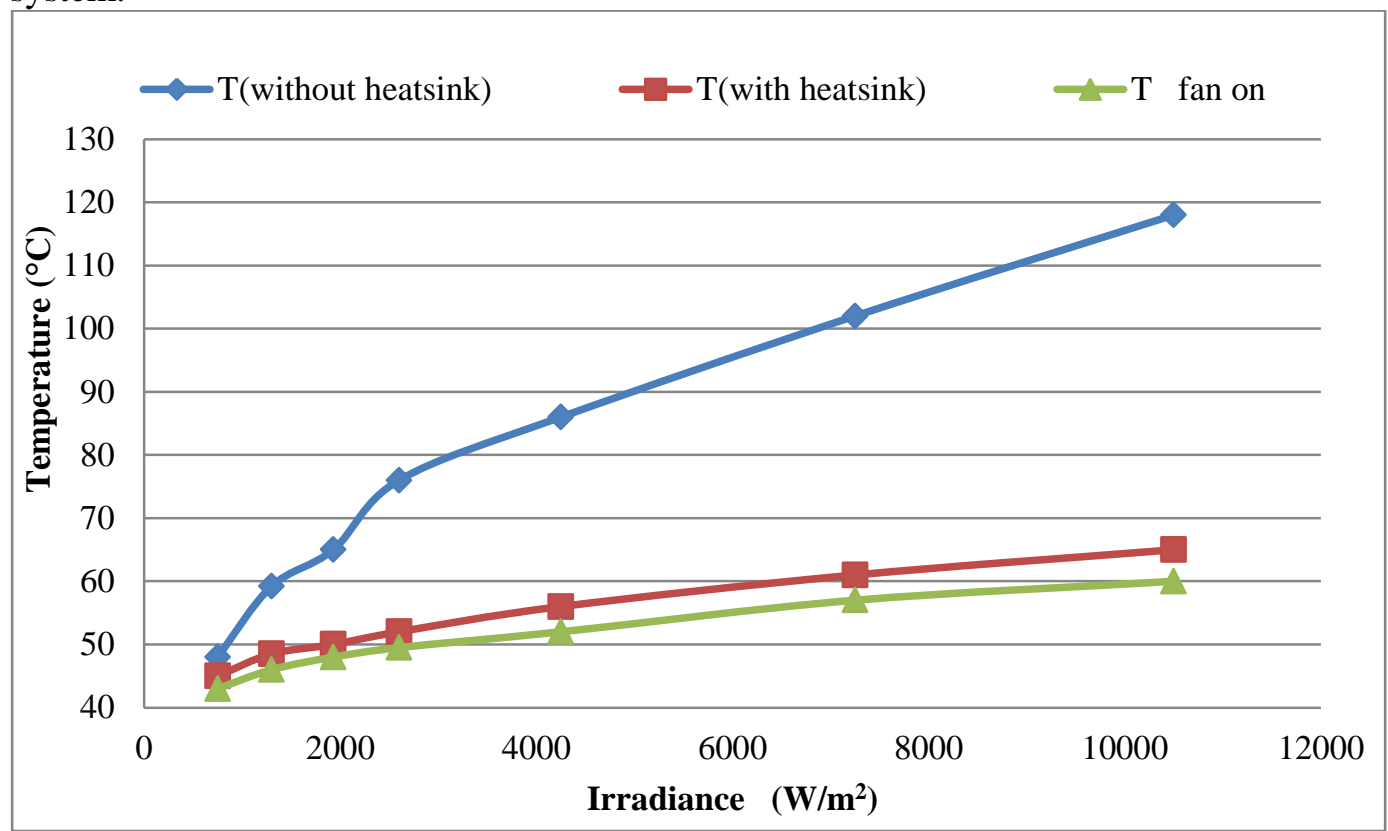

Figure 2-The difference in solar cell temperature with irradiance for three cases; without (heat sink), with (heat - sink) and with (heat - sink + fan on)

Figure-2 shows the effects of the (heat-sink) system of solar cell cooling in reducing the temperature, as well as the slight additional heat reducing effect of the (heat-sink + fan on) system.

From the I-V characteristic curves, it is observed that the increased levels of solar radiation on the surface of the solar cell clearly affected the performance of the solar cell which was without cooling, due to the high temperature. On the contrary, the other two cases were affected less by higher levels of solar radiation, due to the presence of a cooling system that works to dissipate the heat generated in the solar cell.

Increasing the temperature in the solar cell to higher levels leads to an increase in the random vibrations of the electrons and thus collisions and resistance to the photo current generated.

The values of the power produced by the solar cell vary according to the levels of solar radiation; the higher the levels of solar radiation falling on the surface of the cell, the greater the percentage of photon reactions with the electrons of the solar cell material to produce the photo current., Figure-3 shows the change in the power values resulting from the solar cell for the three cases. There will be several associated effects when increasing the rates of solar radiation, which will lead to an increase in the temperature of the solar cell. The high temperature of the solar cell will affect the resistance of the cell material $\left(\mathrm{R}_{\mathrm{sh}}\right)$ and the resistance of the contacts $\left(\mathrm{R}_{\mathrm{S}}\right)$, changing the resistance to the generated light current and leading to its consumption as heat. These effects will reduce the cell voltage, which reduces the power produced from the solar cell. 


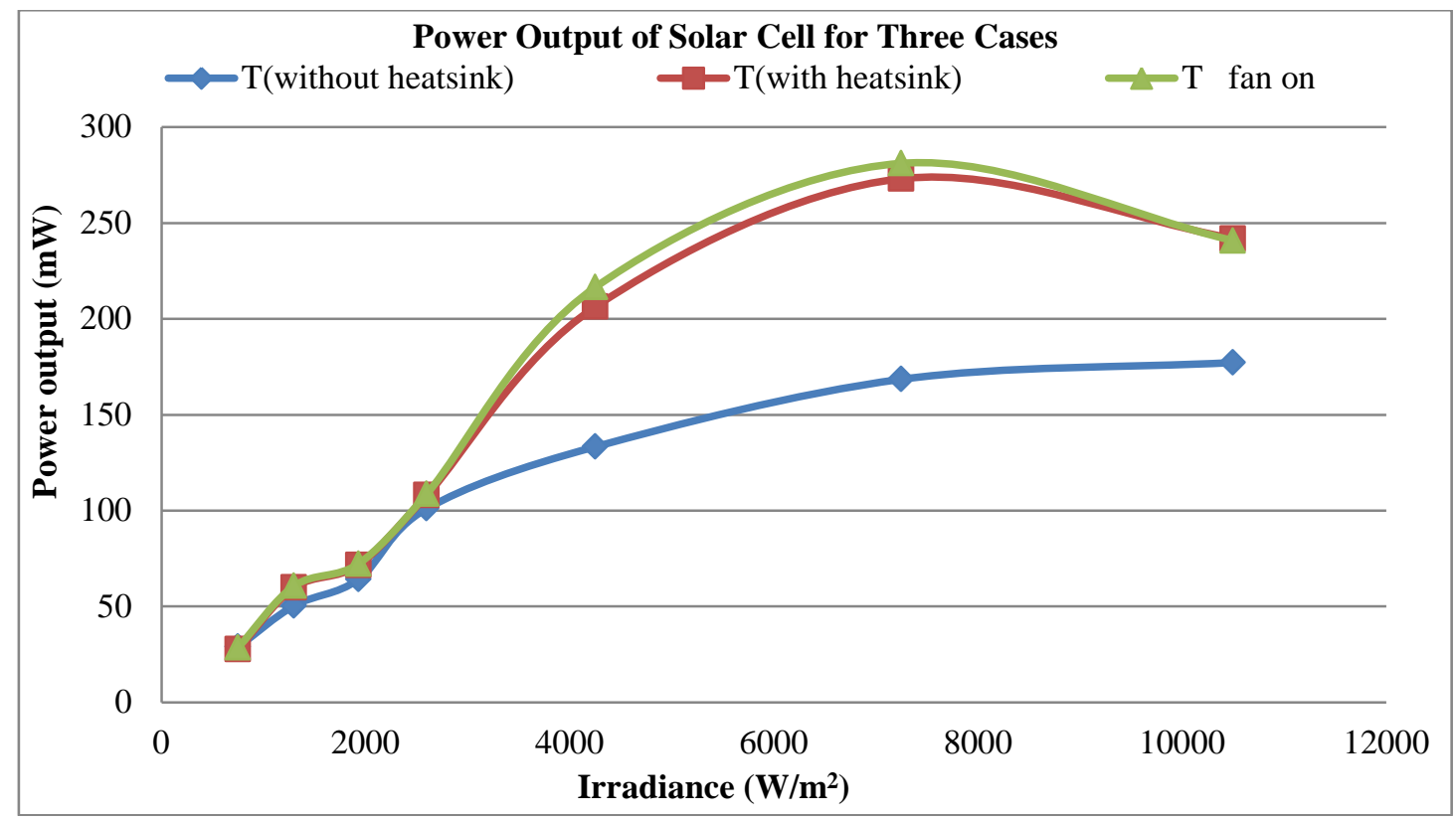

Figure 3- Power output of solar cell with irradiance

The results showed that the efficiency increases from $3.3 \%$ to $10.2 \%$. Figure- 4 shows that the efficiency of the solar cell changes with increasing levels of solar radiation.

The effects of solar radiation levels on changing the efficiency of the solar cell, as well as the effects of the cooling system on increasing efficiency, are evident. This leads to the situation in which the cooling becomes useless and needs to be replaced with a better cooling system, which increases the cost of the system.

With the increase in the rates of solar radiation on the cell, along with the different effects that accompany this increase, there will be a difference in the ratio of the absorbed and interacting photons with the electrons of the material. This leads to the recombination of the (electron-hole), which works to fluctuate the output power of the solar cell. This productivity of the solar cell limits which of the two processes is more influential than the other. An interaction occurs between the photons and the electrons of the material. The production of photo current or (electron - hole) recombination takes place due to changes in the resistance of the material $\left(\mathrm{R}_{\mathrm{sh}}\right)$ and the resistance of the contacts $\left(\mathrm{R}_{\mathrm{S}}\right)$, as a result of the increase in temperature due to the high rates of solar radiation.

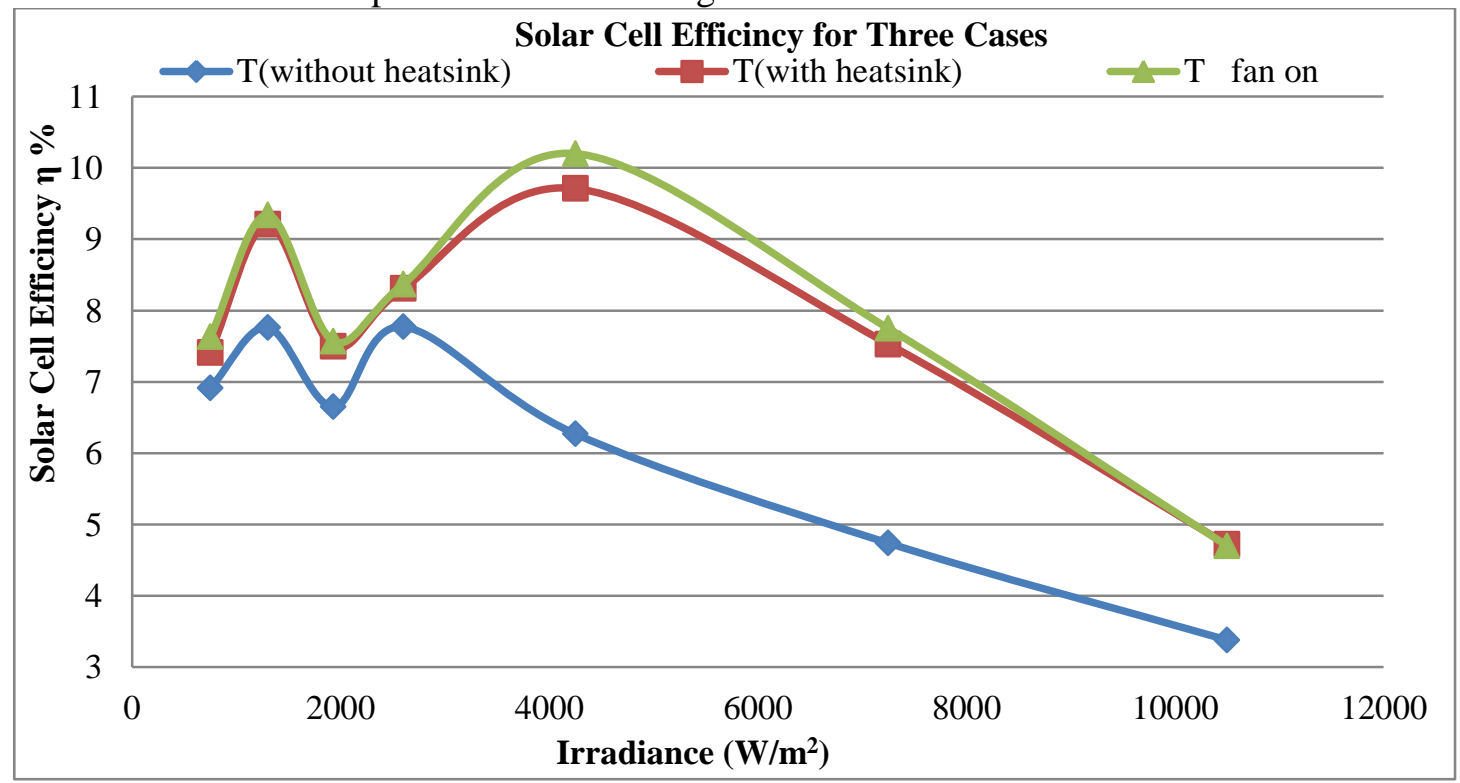

\section{Conclusions}

Figure 4- Solar cell efficiency with irradiance

Silicon solar cells with optics concentrator can be used to increase solar cell output to limited 
conditions, without decreasing efficiency, especially in cold climatic conditions. In the summer, the concentration value cannot be exceeded to higher values because the heat dissipation will require high cooling and thus consumes high energy, because the ambient temperature is high. The solar cell is damaged due to the high solar concentration. Silicon solar cell output may be increased in an CPV system if a cooling system is used as heat sink.

\section{References}

1. Sameh. M. El -Sayed, Wagdy R. Anis, Ismail M. Hafez. 2015. The Effect Of Temperature On The Performance Of PV Array Operating Under Concentration, International Journal of Scientific \& Technology Research, 4(08), August, . ISSN 2277-8616.

2. David Li*, Mehtaab Sawhney, Richard Kurtz, Lorraine Solomon, Jeanette Collette. 2014. Impact of the Location of a Solar Cell in Relationship to the Focal Length of a Fresnel lens on Power Production. Energy and Power, 4(1): 1-6 DOI : 10.5923/j . ep. 20140401.01.

3. Johan Nilsson. 2005. Optical Design and Characterization of Solar Concentrators for Photovoltaics , Division of Energy and Building Design Department of Architecture and Built Environment Lund University Faculty of Engineering LTH, Report EBD-T--05/6. ISSN 1671-8136 ISBN 9185147-15-X.

4. Mario González Montes, Juan Carlos Martínez-Antón, Daniel Vázquez Moliní, Antonio Álvarez Fernandez-Balbuena, and E. Bernabeu. 2014. Achromatic Fresnel Lens with Improved Efficiency for PV Systems. International Journal of Photo energy, Volume 2014, Article ID 787392, 9 pages. Hindawi Publishing Corporation.

5. Royne, C. J. Dey, and D. R. Mills. 2005. "Cooling of Photovoltaic Cells under Concentrated Illumination: a Critical Review," Solar Energy Mater. and Solar Cells, 86: 451-483.

6. Nguyen Xuan Tien and Seoyong Shin. 2016. A Novel Concentrator Photovoltaic (CPV) System with the Improvement of Irradiance Uniformity and the Capturing of Diffuse Solar Radiation. Appl. Sci., 6: 251; doi:10.3390/app6090251 .

7. W.T. Xie, Y. J. Dai , R. Z. Wang, K. Sumathy. 2011. Concentrated solar energy applications using Fresnel lenses: A review. Renewable and Sustainable Energy Reviews 15- 2588-2606.

8. Arias-Rosales, A., Barrera-Velásquez, J., Osorio-Gómez, G., \& Mejía-Gutiérrez, R. 2014. Designing a concentrating photovoltaic (CPV) system in adjunct with a silicon photovoltaic panel for a solar competition car. Energy Harvesting and Storage: Materials, Devices, and Applications $\mathrm{V}, 9115,91150 \mathrm{~W}$.

9. Green, M. A., Emery, K., Hishikawa, Y., Warta, W., \& Dunlop, E. D. 2015. Solar cell efficiency tables (Version 45). Progress in Photovoltaics: Research and Applications, 23(1):1-9.

10. Hornung, T., Steiner, M., \& Nitz, P. 2012. Estimation of the influence of Fresnel lens temperature on energy generation of a concentrator photovoltaic system. Solar Energy Materials and Solar Cells, 99: 333-338.

11. Jing, L., Liu, H., Zhao, H., Lu, Z., Wu, H., Wang, H., \& Xu, J. 2012. Design of novel compound Fresnel lens for high-performance photovoltaic concentrator. International Journal of Photoenergy.

12. Li, D., Sawhney, M., Kurtz, R., Solomon, L., \& Collette, J. 2014. Impact of the Location of a Solar cell in Relationship to the Focal Length of a Fresnel Lens on Power Production. USA: Department of science, Commack High School, Energi and Power journal.

13. Xie, W. T., Dai, Y. J., Wang, R. Z., \& Sumathy, K. 2011. Concentrated solar energy applications using Fresnel lenses:A review. In Renewable and Sustainable Energy Reviews, 15(6): 2588-2606.

14. Tomas Markvart. 2000 .Solar Electricity .Unviersity of southampton.UK.

15. Wu, Y., Eames, P., Mallick, T., \& Sabry, M. 2012. Experimental characterisation of a Fresnel lens photovoltaic concentrating system. Solar Energy, 86(1): 430-440.

16. Sierra, C., \& Vazquez, A. J. 2005. High solar energy concentration with a Fresnel lens. Journal of Materials Science, 40(6): 1339-1343.

17. Royne, A., Dey, C. J., and Mills, D. R. 2005. "Cooling of Photovoltaic Cells Under Concentrated Illumination: A Critical Review," Solar Energy Materials and Solar Cells, 86(4): 451-483, April 2005.

18. M. A. Farahat. 2004. "Improvement the Thermal Electric Performance of a Photovoltaic Cells by Cooling and Concentration Techniques," 39th UPEC International, Bristol, 2: 623-628. 